\title{
Islamist Exegesis of Q 3:110: The Islamic Doctrine of the Responsibility to Protect
}

\author{
Brannon Wheeler
}

\begin{abstract}
Is there an Islamic version of the UN doctrine of the "Responsibility to Protect"? Are Muslims obligated to defend their own community, and to save the rest of the world from tyranny and oppression? The UN doctrine commits member states to p rotect people from certain types of harm, and specifically includes protecting populations from their own governments. If a comparable Islamic doctrine exists, it is especially ironic that the UN doctrine is so frequently applied to Muslim majority countries in the Middle East. This irony allows for a new perspective on the continuing conceptual and physical conflicts between western powers and states in the Middle East.
\end{abstract}

\section{Introduction}

The "Responsibility to Protect" (R2P) doctrine, ratified at the 2005 World Summit, commits all the member states of the United Nations General Assembly to using "appropriate diplomatic, humanitarian and other peaceful means" to "help protect populations from genocide, war crimes, ethnic cleansing and crimes against humanity." This includes a commitment to

Brannon Wheeler teaches Islamic studies and the history of religions at the United States Naval Academy. He received his PhD from the University of Chicago, and has been a visiting scholar at institutions throughout the Middle East and Europe. He has published ten books, and is currently finishing a book on the camel sacrifice of the prophet Muhammad.

Wheeler, Brannon. 2020. "Islamist Exegesis of Q 3:110: The Islamic Doctrine of the Responsibility to Protect." American Journal of Islam and Society 37, nos. 3-4: 24-49 • doi: 10.35632/ajis.v37i3-4.709 Copyright (c) 2020 International Institute of Islamic Thought 
"take collective action" when "national authorities manifestly fail to protect their [own] populations" from these same four threats. ${ }^{1}$

This doctrine was first defined in a 2001 report of the UN International Commission on Intervention and State Sovereignty, primarily in response to recent events in Rwanda, Kosovo, Bosnia, and Somalia. ${ }^{2}$ In 2005 the socalled "second" Gulf War was at its height. In 2011 the UN invoked R2P as a reason for military intervention to protect civilian population from the threats and actions of the Libyan government. Qatari, UAE, and Jordanian forces fought alongside NATO forces. In 2017, Gareth Evans, one of the primary drafters of the original R2P doctrine, argued that R2P should apply to fighting the Islamic State in Iraq, to protect civilian populations from "genocide" and "mass atrocities" that are "unrivalled in their savagery." Others have argued that R2P applies (or at least should be) to the conflicts in Syria and Yemen.

Given that so much of the conception and invocation of R2P seems to apply to Muslim-majority states in the Middle East, and indeed is directed against Muslim regimes in the Middle East, it is reasonable to ask: Is there an Islamic version of the Responsibility to Protect Doctrine? The following pages attempt to answer this question by examining two broad and interrelated ideas. Part one focuses on modern Islamist discourse concerning the responsibilty of Muslims to "save the world" based on the exegesis of the identity and eschatological rôle of the "best community" mentioned in Q 3:110. Part two analyzes classical and modern Muslim conceptions of "migration" (hijra), as the religious obligation both to emigrate and to protect migrants. The conclusion suggests the irony of the clash between the UN doctrine of R2P and the Muslim community's understanding of its response to the results of that doctrine.

\section{Saving the World}

In 2006 President Mahmoud Ahmedinejad of Iran delivered a speech in Tehran at the opening session of the annual International Conference of Mahdaviat Doctrine. ${ }^{3}$ His speech was about the coming of the long-awaited messianic Mahdī al-Qā’im who would appear at the end of time and preside over an era of universal peace and justice. During the course of the speech, President Ahmedinejad stressed that Shi'ī Muslims accepted all religions as true and that the Mahdi would be recognized by all people when he returned-Christians would see Jesus, Jews their Messiah, Buddhists the future Buddha Maitreya, and Muslims their Mahdī. 
He explained that there were two main views, shared not only by Muslims but also by those of other religions, concerning how we, as humans, could hasten and help to bring about this messianic utopian age. One view is that found most commonly in classical Imāmì Shi'ì scholarship and traditions-that the return of the Twelfth Imām was to be preceded by the dissolution of religion, an increase in injustice, and the spread of chaos. The sixth Imām Ja'far al-Ṣādiq is recorded as saying that the Mahdī will return when injustice, tyranny, and moral degradation have overtaken the earth. ${ }^{4}$ Such traditions are known from non-Shi'i sources as well, including reports from the prophet Muhammad found in the authoritative collections of hadith. ${ }^{5}$

This sort of eschatology, Ahmedinejad claimed, was behind the actions of people like Abū Muṣ ab al-Zarqāwī, spreading chaos and irreligion in an attempt to bring about the apocalypse. ${ }^{6}$ Certain Sunni traditions, recorded by Shi'i scholars, linked back to sayings of the prophet Muhammad and his followers, foretell specific hardships befalling the people of Syria and Iraq. ${ }^{7}$ The tenth and eleventh century Shi'i s scholar known as Shaykh al-Mufìd (d. 1022) cites a tradition that there will be a conflict in Syria that will destroy the country at the end of time, and another prophecy describing the destruction in Baghdad caused by fire from the sky, widespread war, and blood coating the people of Iraq. ${ }^{8}$

The other view, according to Ahmedinejad, is that the Mahdī al-Qā'im would appear and usher in the eschaton when the people of the earth had created a world that was already full of the peace, justice, and prosperity that the millennial reign of the Mahdi represents. Muslim eschatology does contain references to specific events, such as the Arabs resisting and throwing off the influence and occupation of foreign powers at the end of time. ${ }^{9}$ Muslim exegetes understand Q 2:30 as God entrusting humanity with custodianship of the earth and its inhabitants. ${ }^{10}$ Not unlike the Jewish notion of "fixing the world" (tikkūn ha- oläm), ${ }^{11}$ this alternate Islamic conception of the Mahdī al-Qā'im understands the coming messianic age not as waiting for a savior but as a call for social action (backed by economic, political, and military means) to reform the world and re-establish the Muslim world community (umma). The age of the Mahdi al-Qā'im is one of social justice, bounty of the earth, human security, and the harmony of all religions. ${ }^{12}$

Such eschatological thinking is rooted in Islamist discourse drawing on themes and principles embedded in classical, traditional Islamic thought. Both Sunnī and Shi'i traditions contain prophecies of how the 
Muslim world community (umma) is to arise at the end of time to save the world from ruin and usher in the apocalypse. In large part, the models articulated by Ahmedinejad rely on the Muslim exegesis and application of Q 3:110 and related verses.

You are the best community (umma) produced for humanity, commanding what is known to be right ( $\left.a l-m a^{\prime} r u \bar{f}\right)$ and forbidding what is wrong, and believing in God. If only the People of the Book had believed, it would be better for them. Among them are believers but many of them are disobedient.

Classical Muslim exegesis explains that the "best community" are the followers of Muhammad, and that it is this community that will benefit the rest of humanity. In his commentary on Q 3:110-112, the well-known Qur'an exegete Ibn Kathīr (d. 1373) claims that although some scholars say this community is only those early Muslims who fled as refugees with the prophet Muhammad from Mecca to Medina, the verse actually refers in general to all communities that are governed by and follow what is known to be right. ${ }^{13}$

This "best community" is often understood in apocalyptic terms. The prophet Muhammad is reported to have said to his followers that they were the last of "seventy" communities God sent to earth, the best and the one most honored by God. ${ }^{14}$ 'Alì b. Abì Țâlib relates that the prophet Muhammad claimed that his community was the best because he had brought to them, from God, victory in battle and the "keys to the earth" unlike any prophet before. ${ }^{15}$ Many Muslim exegetes cite a number of hadith reports in which the prophet Muhammad says his community will save the world, superseding the communities of Moses (the Jews) and Jesus (the Christians). ${ }^{16}$ In other hadith reports the prophet Muhammad states that only one community out of the seventy raised upon the earth will enter paradise, the other sixty-nine being punished in Hell. ${ }^{17}$ Comparing this "best community" to Muslims martyred in an apocalyptic battle in Syria, Ahmad b. Hanbal relates that it is this one chosen community, consisting of only 70,000 righteous believers, that will enter paradise without being judged. ${ }^{18}$

More recent Islamist discourse likewise emphasizes and draws upon the apocalyptic character of Q 3:110. The modern Egyptian thinker Sayyid Qutb (1906-1966), for example, says that this "best community" consists of the true believers who do not break into sects and disagree after clear signs from God have come to them. They are the ones who have shining faces 
from the mercy of God, not those whose faces are dark and assigned a great punishment. ${ }^{19}$ Quṭb identifies this chosen community with a "vanguard" of responsible Muslims who will pave the way for the re-establishment of the universal Muslim community.

There must be a vanguard committed to this undertaking, a vanguard resolved to stay the course and navigate a vast sea of jahiliyah that has taken root in every region on earth. As it proceeds, this vanguard must, on the one hand, remain detached from the surrounding jahiliyah and, on the other hand, keep in contact with it. The vanguard committed to such an undertaking must recognize the 'signposts along the road' to know the nature of its role, the essence of its task, the purpose of its commitment, and the point of its departure on this long journey. It must also recognize its position in relation to the jahiliyah that is firmly entrenched throughout the globe. ${ }^{20}$

Qutb's placing of this "vanguard" in the context of a modern version of the "jahiliyah" into which the prophet Muhammad and his followers formed the original umma is consistent with classical exegesis of Q 3:110 and other verses. ${ }^{21}$ The famous Iranian historian and exegete al-Tabarī (d. 923) refers to an interpretation of the verse in which Qatādah b. al-Nu'mān reports that he heard the prophet Muhammad say that this "best community" will be singled out by God from all the rest of the world on the Day of Resurrection. ${ }^{22}$

Along these same lines, Hassan al-Bannā (1906-1949) - the founder of the Muslim Brotherhood in Egypt—cites Q 5:54, linking the "best community" of Q 3:110 to an elect few sent by God:

Then God will bring a people whom he loves and who love him, humble toward believers and powerful against unbelievers, striving in the way of God, and fearing not the reproach of any reproacher. That is the bounty of God, which he brings to whom he will. (Q 5:54)

A report, given on the authority of al-Hasan al-Bașrī (d. 728), cited by the Khorasānī hadīth specialist Ahmad b. Husayn al-Bayhaqī (d. 1066) in his Dalä'il al-nubuwwa, identifies the "people whom he [God] loves and who love him" as the first Caliph Abū Bakr and his followers who fought against the Arabs who rejected Islam after the death of the prophet Muhammad. ${ }^{23}$ The Iranian hadìth scholar 'Abd al-Rahmān Ibn Abì Hạtim (d. 890) and al-Ṭabarī both relate that al-Dahḥ̄āk said Abū Bakr and his followers were loved by God because they "did jihād" (jähada-hum) against the apostates 
during the so-called "wars of apostasy" until they returned to Islam. ${ }^{24} \mathrm{By}$ linking Q 5:54 with Q 3:110, al-Bannā establishes that the "best community" is the one that is commissioned with re-establishing the true Muslim umma, implementing what is known to be right and protecting against what is wrong.

The modern Syrian writer Muhammad Rashīd Riḍā (1865-1935) similarly compares the "best community" of Q 3:110 with a modern-day version of those Muslims who followed the prophet Muhammad in establishing the original Islamic umma in the face of opposition from the pagan Arabs. In his commentary, Tafsīr al-manār, on Q 3:110, Riḍā cites Q 8:74-75:

Q 8:74 Those who believed, emigrated (häjarū) and strove in the path of God (jāhadū fì sabil allāh), those who gave shelter and aided, truly they are the believers. For them is forgiveness and noble sustenance. 75 Those who believed [after the Hijra], emigrated (hājarū), and strove (jāhadu) with you, they are of you...

Both al-Bannās link to Q 5:54 and Riḍās reference to Q 8:74-75 emphasize that the "best community" is to be that one consisting of believers who actively work, following the example of the prophet Muhammad and his earliest followers, toward the re-establishment of the umma. ${ }^{25}$

For the Ayatallah Ruhollah Khomeini (1902-1989) the first Supreme Leader in Iran (1979-1989), the jurists (fuqaha') must take on the initiative to lead other people toward the re-establishment of the Islamic state that can alone effectively command what is right and forbid what is wrong in the world. ${ }^{26}$

Now that no particular individual has been appointed by God to assume the function of government in the time of Occultation, what must be done? Are we to abandon Islam? Do we no longer need it? Was Islam valid for only two hundred years?

Not to have an Islamic government means leaving our boundaries unguarded. Can we afford to sit nonchalantly on our hands while our enemies do whatever they want?.... Or is it rather that government is necessary, and that the function of government that existed from the beginning of Islam down to the time of the Twelfth Imam is still enjoined upon us by God after the Occultation, even though he has appointed no particular individual to that function? 
The two qualities of knowledge of the law and justice [required of the leader of the Muslim community] are present in countless fuqahä of the present age. If they would come together, they could establish a government of universal justice in the world.

The jurists are those specializing in extracting from revelation those principles which are to be applied to creating the Islamic state. ${ }^{27}$ Although it is specifically Imāmī Shi'i in character, predicated on the idea that the Imām will be the individual most qualified to lead the Muslim community once it is re-established, the outlook of Khomeini is in agreement with that of other Islamist thinkers like Quṭb and al-Bannā. In his commentary on Q 3:110, the Egyptian scholar Jalāl al-Dīn 'Abd al-Rahmān al-Suyūtị (d. 1505) relates that the "chosen" community is to be identified with those God "chose with knowledge over the worlds" in Q 44:32. ${ }^{28}$

And not unlike Qutb and al-Bannā, Khomeini maintains that the purpose of this jurist custodianship is to protect. Recalling the classical exegesis of Q 3:110, Khomeini insists that the best community to lead is that which is not divided and broken into conflicting sects. ${ }^{29}$

In the past, we did not act in concert and unanimity in order to establish proper government and overthrow treacherous and corrupt rulers. Some people were apathetic and reluctant even to discuss the theory of Islamic government, and some went so far as to praise oppressive rulers. It is for this reason that we find ourselves in the present state. The influence and sovereignty of Islam in society have declined; the nation of Islam has fallen victim to division and weakness; the laws of Islam have remained in abeyance and been subjected to change and modification; and the imperialists have propagated foreign laws and alien culture among the Muslims through their agents for the sake of their evil purposes, causing people to be infatuated with the West. It was our lack of a leader, a guardian, and our lack of institutions of leadership that made all this possible. (28)

And this duty to protect is founded not on the protection only of co-religionists but on upholding the revealed principles of safeguarding the oppressed and weak from tyranny and oppression.

Hundreds of millions of Muslims are hungry and deprived of all forms of health care and education, while minorities comprised of the wealthy and powerful live a life of indulgence, licentiousness, and corruption. The hungry and deprived have constantly struggled to free themselves from the oppression of their plundering overlords, and their struggle 
continues to this day. But their way is blocked by the ruling minorities and the oppressive governmental structures they head. It is our duty to save the oppressed and deprived. It is our duty to be a helper to the oppressed, and an enemy to the oppressor.

It is the duty of Islamic scholars and all Muslims to put an end to this system of oppression and, for the sake of the well-being of hundreds of millions of human beings, to overthrow these oppressive governments and form an Islamic government. (25)

The Hamas charter of 1988 also opens by citing Q 3:110-112. ${ }^{30}$ The charter invites all Muslims (article four) to help re-establish the "best community," at a "time when Islam has disappeared from life" (article nine), to "be a support of the weak, a victor to the oppressed; with all its might, using all of its energy, to realize the truth and defeat the falsehood, by words and action, here and everywhere it can reach and affect a change" (article ten). ${ }^{31}$

The purpose and mission of this vanguard is to restore the original Muslim community, one that has been lost along with the institution of right and wrong that is meant to govern the world. Qutb specifically links the nascent vanguard with the earliest Muslims following the prophet $\mathrm{Mu}$ hammad.

This umma must be restored to its original form so that Islam can once again perform its appointed role as leader of humankind. It is essential to excavate this umma buried beneath the rubble accumulated from generations of ideas, practices, and systems entirely unrelated to Islam and the Islamic way.

Islam is unable to perform this role, however, unless it is actualized in society or in a community...The Muslim community has not existed for many centuries, for it is not a 'land' in which Islam has been located, nor is it a 'people' whose forebears lived under an Islamic system at one time in history. Rather 'the Muslim community' is a group of human beings whose customs, ideas, practices, laws, statues, values, and guidelines all emanate from the Islamic way of life (manhaj). The community with these characteristics ceased to exist the moment that rule of God's law vanished from the earth entirely.

Bannā likewise argues that only true Islam, embodying the values revealed to the prophet Muhammad and applied by his earliest followers, can perform this mission. 
No regime in this world will supply the renascent nation with what it requires in the way of institutions, principles, objectives, and sensibilities to the same extent that Islam supplies every one of its renascent nations. The noble Qur'an is full of passages descriptive of this particular aspect, and contains numerous exemplary parables concerning it-in general or in detail-while it deals with these aspects clearly and precisely. No nation adheres to it without succeeding in its aspirations.

This is not unlike the sort of language used by Mu'ammar Qadhdhāfī (19422011) in his call for the construction of a new Islamic society that would hearken back to the revealed principles upon which the original Muslim community was founded. ${ }^{32}$

The time has come to manifest the truth of Islam as a force to move mankind, to make progress, and to change the course of history as we changed if formerly.

We are a people with authentic roots set deep in history, and the truths about which we speak were present before the formation of American society which leads to capitalism, and present before Marxist philosophy, the philosophy of the communists who lead communist society... because of this, we call it 'the third theory' in the sense that we have here a third thing which may be the first, in fact, is the first, and also the last. ${ }^{33}$

In this discourse, Islam alone can lead humanity toward a social, political, and economic order that will preserve universal human rights.

Thus, the world is not led to the true path. We have the true path...it was present before communism and before capitalism. America is only a century old, whereas these words have been present with us for more than a thousand years. The rights of man existed among us before the American society was formed. When we articulated the rights of man, the American continent was devoid of human life. Now they have been present for 200 years and have started bragging that they are the ones who have fashioned the rights of man...also the communist revolution of 1917 is of very recent vintage. ${ }^{34}$

This echoes classical interpretations of Q 3:110, such as that recorded by alTabarī and others on the authority of Mujāhid b. Jabr (d. 722), the student of Ibn 'Abbās (d. 687), that the "best community produced for humanity" is that which commands what is known to be good, protects against what is wrong, and believes in God. ${ }^{35}$ Bannā upholds the Qur'an itself as the source 
of the principles needed to create a more just and socially responsible world order. Qadhdhāfi says the same thing:

We must take the Qur'an as the focal point of our journey in life because the Qur'an is perfect; it is light, and it in are solutions to the problems of man...from personal status...to international problems. ${ }^{36}$

Not only does the Quran record the divine commandment to command the good and forbid the wrong, but it also contains the principles of what informs the "good" and the "wrong", providing answers to the problems of the world.

Also echoing Q 3:110, Khomeini explains that it is these revealed principles embodied in the Islamic umma that can allow Muslims to establish what is right and protect against what is wrong.

In order to assure the unity of the Islamic umma, in order to liberate the Islamic homeland from occupation and penetration by the imperialists and their puppet governments, it is imperative that we establish a government. In order to attain the unity and freedom of the Muslim peoples, we must overthrow the oppressive governments installed by the imperialists and bring into existence an Islamic government of justice that will be in the service of the people.

For Khomeini, the requirement to stand up an elect vanguard that leads to the re-establishment of a community governed by the revealed principles of what is right and wrong for the benefit of all humanity is equivalent to the "act" of Islam.

No one can say it is no longer necessary to defend the frontiers and the territorial integrity of the Islamic homeland; that taxes such as the jizya, kharaj, khums, and zakat should no longer be collected; that the penal code of Islam...should be suspended. Any person who claims that the formation of an Islamic government is not necessary implicitly denies the necessity for the implementation of Islamic law, the universality and comprehensiveness of that law, and the eternal validity of the faith itself.

The apocalyptic nature of the need to implement the revealed principles that will protect the weak and promote righteousness is present in all of these contemporary Islamist thinkers and figures. For Qutb, living in the midst of the Cold War, the existential character of the world-wide crisis means that the obligation for Muslims to act is compelling. ${ }^{37}$ For Qutb, the implementation of the soteriology outlined in Q 3:110 is urgent. 
Humanity today is standing at the brink of an abyss, not because of the threat of annihilation hanging over its head...but because humanity is bankrupt in the realm of 'values', those values which foster true human progress and development...This is abundantly clear to the Western world, which realizes that it cannot provide values for humanity and cannot even persuade itself of the justification for its own existence.

At this critical moment of confusion and disorder, the time of 'Islam' and the 'umma' have arrived.

Bannā, having lived through the Great War and experiencing the effects of the world-wide Depression, heralds a similar urgency:

The civilization of the West, which was brilliant by virtue of its scientific perfection for a long time, and which subjugated the whole world with the products of this science to its states and nations, is now bankrupt and in decline. Its foundations are crumbling, and its institutions and guiding principles are falling apart. Its political foundations are being destroyed by dictatorships, and its economic foundations are being swept away by crises. The millions of its wretched unemployed and hungry offer their testimony against it, while its social foundations are being undermined by deviant ideologies... Its people are at a loss as to the proper measures to be taken and are wandering far astray.

Muslims have a pressing duty not only to protect other Muslims but to save the whole of humanity from imminent destruction. Using the exegesis of Q 3:110 and other verses, these Islamist thinkers developed a kind of "doctrine" elaborating on the responsibility of the Muslim community not only to protect its members but also to rescue the whole of humanity from its impending (and self-imposed) demise.

\section{Hijra}

The calls for action articulated by each of these Islamist thinkers can be seen as the application of an eschatological vision of Q 3:110 to a major if not global and existential threat to human security. For Hasan al-Bannā it is the Great Depression, for Sayyid Qutb and Mu'ammar Qadhdhāfī it is the Cold War, and for the Ayatallah Khomeini it is the colonialist intrusions (including Israel) into the region as exemplified by US and European support for tyrannical regimes like that of the Shah in Iran. ${ }^{38}$

In the twenty-first century, one of the most pressing crises facing Muslims around the world is the refugee crisis. Especially within the Middle 
East but also affecting Muslim communities in other parts of the world such as Myanmar and the Horn of Africa, the displacement of large populations of Muslims and others has reached critical proportions. Examples include refugees from Afghanistan (6.3m in 1990, 2.6m in 2017), Iraq (1.1m in 1990), Myanmar (1.1m in 2017), Palestine (5m in 2018), Somalia (470k in 1990, $1 \mathrm{~m}$ in 2017), and Syria (6.3m in 2017), a total of almost 7 million for the Middle East and North Africa as a whole in 2017. ${ }^{39}$ As of 2017 there were 22 million people in Yemen at risk, 2 million internally displaced, more than 6 million facing starvation and a cholera epidemic. ${ }^{40}$ Turkey is host to 3.5 million refugees, Lebanon hosts 2 million refugees, Jordan hosts 1.2 million Syrian and half a million Iraqi refugees, and Iran hosts almost a million refugees mostly from Afghanistan and Iraq. ${ }^{41}$

Central to Islamic thinking about social responsibility and nation building, from classical times to today, is the issue of refugees, and forced emigration in particular. In his commentary on Q 3:110, al-Suyūtị cites a number of Muslim exegetes who maintain that the "best community produced for humanity" consists of those who emigrated with the prophet Muhammad from Mecca to Medina. The interpretation is related on the authority of Ibn 'Abbās, and is reported by Ahmad b. Hanbal, Ibn Jarīr al-Ṭabarī, Ibn Abī Ḥātim, Ibn Abī Shaybah, 'Abd al-Razzāq, and others. ${ }^{42}$ Islamic history valorizes the special status of these "refugees" (muhäjirīnn), the early Muslims who were compelled to flee from their homes in Mecca in order to resettle and build the first umma in Medina. ${ }^{43}$

The earliest Muslim communities outside of the Arabian peninsula were founded as "camps" ( $a m s \bar{a} r$ ) apart from the larger already established cities populated by non-Muslims. According to a tradition attributed to Abū Dharr, Syria was designated as the "land of migration" (dār al-hijra), ${ }^{44}$ and 'Uthmān b. 'Affān is reported to have used the term "refugees" (muhäjirūn) when talking about the people of Syria. ${ }^{45}$ The prophet Muhammad instructed his followers to invite the enemy to leaves their homes and join the Muslim "refugees" (muhājirūn) in the "abode of the refugees" (dār al-muhājirūn). ${ }^{46}$ 'Umar b. al-Khattạa said the best Muslim is he who sells everything, abandons his home, and joins the Muslims in "one of the abodes of migration" (dār min dūr al-hijra). ${ }^{47} \mathrm{Sa} d \mathrm{~d}$ b. Abī Waqqas founded the camp-city of Kūfah when told by 'Umar b. al-Khațāb to build a "dār al-hijrah wa manzil al-jihäd." ${ }^{38}$ A number of Muslim sources use the term "refugees" or "migrants" (muhäjirūn) to refer to the Muslims living in the "camp-cities" (amșār) founded by the early Muslim conquerors. ${ }^{49}$ 
According to Islamic jurisprudence certain circumstances require that Muslims migrate from their home to another land. These legal rulings are, in part, based on the migration of the prophet Muhammad and his followers, first to Ethiopia and then to Medina, but also on the example of earlier prophets. Muslim exegetes point to Abraham's "hijra" in particular, from his home in Iraq, where he was persecuted for his religion, to the Holy Land, where he established what would later become known as the religion of Islam: "Lot believed, and [Abraham] said: 'I am a refugee (muhajir) for my Lord. He is Mighty, Wise" (Q 29:26). Muslim exegetes compare this verse to the migration of the prophet Muhammad, and to the migration of Muslims following the example of the prophets. The contemporary Saudi scholar Sheikh Șālih b. Fawzān al-Fawzān describes the example of Abraham as establishing the necessary practice of migration:

The hijrah in this sense is among the traditions of Ibrahim (a.s) who said, "Lo! I am going unto my Lord Who will guide me" (As-Saffat 37:99). The verse refers to Ibrahim's emigration from the country of disbelievers, seeking faith. Some of his offspring accompanied him to Ash-Sham, where Al-Aqsa Mosque is located in Palestine, and then, accompanied by some others of his offspring, he moved to Al-Hijaz, where the Sacred Mosque is situated in Makkah. This is stated in the invocation mentioned in the verse that reads, "Our Lord! Lo! I have settled some of my posterity in an uncultivable valley near unto Thy holy House" (Ibrahim 14:37).50

He then cites a hadìth report preserved by Abū Dāwūd in which the prophet Muhammad states that this practice of migration is in effect until the end of time..$^{51}$

Verses from the Qur'an and hadith reports emphasize that migration is a practice incumbent upon all Muslims. Both classical and modern scholars argue that Q 74:5 "avoid impurity" (al-rujza fa-hjur) means emigrating from a place where polytheists worship idols. ${ }^{52}$ 'Abdallāh b. 'Amr relates that a man asked the prophet Muhammad: "Which hijra is best?" and the Prophet responded by saying: "The hijra from what your Lord dislikes." 53 In a hadìth report preserved by Abū Dāwūd, the Prophet says: "Hijra will not end until repentance ends, and repentance will not end until the sun rises in the west." ${ }^{54}$ Another report preserved by al-Bukhārī relates that the prophet Muhammad said: "A Muslim is one who avoids harming Muslims with his mouth or body, and a migrant (muhäjir) is one who has abandoned all that God forbids." ${ }^{55}$ Ibn Mājah preserves a report in which the prophet 
Muhammad says: "The believer is one from whom people's wealth and lives are safe, and the migrant is the one who forsakes mistakes and sins." ${ }^{36}$

The well-known Spanish and Maghrebi jurist and philosopher Abū al-Walīd Muhammad b. Ahmad Ibn Rushd (d. 1198) states that hijra is obligatory for Muslims:

It is obligatory, according to the Qur'an, Sunnah and scholarly consensus, for anyone who becomes Muslim in a non-Muslim ( $k \bar{a} f i r)$ land to migrate from there and settle in a Muslim land, and not to live among non-Muslims (mushrikün) or settle among them. That applies whether or not he is able to practice his religion openly or he is forced to follow non-Muslim (kufr) religion. ${ }^{57}$

This obligation is based on a number of verses in the Qur'an, including $Q$ 4:97-100 and Q 8:72:

Whoever migrates for the sake of God (yuhājir fì sabìl allāh) will find on earth many places (murägham-an kathir-an) and abundance (wasa'atan). When a person leaves his home as a migrant (muhäjir) for God and his apostle, and subsequently death overtakes him, his reward is already incumbent upon God. God is Forgiving, Merciful. (Q 4:100)

In his commentary on Q 4:100, Muhammad b. Aḥmad al-Qurțubī compares the act of migrating from one's home to the migration of the prophet Muhammad and his followers from Mecca, where they were unable to follow Islam. ${ }^{58}$ Qatāda b. Nu'mān claims that the word "abundance" (wasa'atan) refers not only to sustenance but to a place where Muslims will find divine guidance from error and can gain wealth and not be persecuted. ${ }^{59}$

Those who believe, migrate (hājirū), and fight (jāhidū) with their wealth and their lives for the sake of God, and those who gave shelter and aided, they are protectors of each other. But those who believed but did not migrate, you are not obligated to protect them until they migrate. If they ask you for help in religion, then help is incumbent upon you except against a people with whom you have a treaty. God is Seeing of all you do. (Q 8:72)

According to al-Suyūți, this verse indicates that Muslims are required to migrate and live among other believers with their residences, their property, and their wealth..$^{60}$ Muslims are obligated to believe, to migrate, and to fight. Ibn Kathir explains that the context of the verse was the tension between those Muslims who followed the prophet Muhammad from Mecca and those who joined after he arrived in Medina, but the abiding legal 
implication of the verse is that Muslims who do not migrate are not guaranteed the protection of the larger Muslim community they refuse to join. ${ }^{61}$

Muslims are obligated not only to migrate but also to protect other Muslims who do migrate. Some modern exegetes argue that Q 4:97-100 makes this evident since it establishes that the earth belongs to God as a place of refuge for the helpless and oppressed. ${ }^{62}$ Others point to the history of Muslims taking in and protecting refugees during the first Crusade, the aftermath of the Reconquista, and during World War II in Albania. ${ }^{63}$ Many scholars cite a hadìth report, given on the authority of Jābir b. 'Abdallāh al-Anșārī, in which the prophet Muhammad declares all of the earth to be sacred and pure and a mosque. ${ }^{64}$ Alongside Q 4:97-100, this saying is taken to mean that refugees should be given protection wherever they might be in the world. ${ }^{65}$ The so-called "Constitution of Medina" (mìthāq al-madina), made between the prophet Muhammad and the people of Medina, is understood by many Muslim scholars to establish a safe haven for the refugees from Mecca, forced to flee from religious persecution. ${ }^{66}$

Muslim jurists and Islamic legal theory in general has always recognized the centrality and interconnected nature of protecting both the Muslim community and its expansion to include the protection of other non-Muslims under the umbrella of Islam. The connection between "hijra" and "jihā $d$ " has a long history of development in Muslim jurisprudence tied to the idea that, as "jihād" spreads Islamic civilization, more people, Muslim and non-Muslim alike, are brought under the protection of Islam. ${ }^{67}$ Muslim doctrine and practice of jihād as expansion of civilization continued the ideas and practices of the Greeks and Romans in the region before them. In this legal theory, holy warfare was an expansion of Islam and peace (dār al-islām) to replace war and unrest (dār al-harb). This is exemplified in the original use of "dàr al-hijra" to delineate the scope and content of Muslim civilization. ${ }^{68}$ Muslim exegesis of Q 16:110 claims that it was the "hijra" and "jihād" of certain Meccans that allowed for God's forgiveness and their inclusion in the Muslim community.

Muslim scholars point out that some of these concepts and obligations are rooted in the twin concepts of "neighbor-ness" (jiwār) and "safe conduct" ( $a m \bar{a} n$ ) found in the traditional Arab culture which was observed by the prophet Muhammad and incorporated into Islam. The prophet $\mathrm{Mu}-$ hammad himself was orphaned at an early age but was protected by his extended family and his tribe. According to 'Alī b. Ibrāhīm al-Halabì (d. 1643), the Egyptian-born biographer of the prophet Muhammad, it was 
considered shameful if a child was only nursed and nurtured by its biological mother alone. ${ }^{69}$ In his biography of the prophet Muhammad, Ibn Ishāq relates how Halìma, the foster mother of Muhammad, was reluctant to return the child to his biological mother because of the blessings she had received while caring for him..$^{70}$ The incident of the Prophet seeking the jiwār protection of the Thaqif tribe in al-Ṭầif is highlighted by Muslim scholars as exemplifying the centrality in Islam of the concept and practice of protecting refugees. ${ }^{71}$ The prophet Muhammad received jiwār protection from al-Mut ${ }^{\mathrm{c} i m} \mathrm{~b}$. ${ }^{\mathrm{A}} \mathrm{Adi}_{\mathrm{i}}{ }^{72}$ and Abū Bakr is reported to have accepted the jiwār protection of Ibn al-Dighna. ${ }^{73}$

The protection offered to the refugee followers of the prophet Muhammad by the Negus (al-Najāshī) in Ethiopia established a precedent reflected in Islamic jurisprudence and in Muslim practice. ${ }^{74}$ Ibn Ishāq reports that the Negus was unwilling to turn the Muslims over to the Meccans because he recognized the biblical character of their beliefs. After the Muslims recited a Quranic passage from the story of Mary, the Negus started to cry and said: "Truly, this and what Jesus taught come from the same source." In a hadīth report preserved by Abū Dāwūd, the Negus is reported to have witnessed that the prophet Muhammad was the "apostle of God" foretold by Jesus. ${ }^{76}$ The Prophet is said to have offered prayers at the death of the Negus because of the protection the latter had offered his followers. ${ }^{77}$

\section{Conclusions}

The concept of "fixing the world" (tikkūn ha-'oläm) is developed from an interpretation of the role of humanity in God's plan for creation: God did not create the world to be perfect, but provided humanity with the capacity, and the mission, to "fix" or "improve" this creation. ${ }^{78}$ Not unlike how Islamists derive their mandate from God's words in Q 3:110 and other passages, Jewish thinkers argue that humanity has the responsibility to perfect itself and save the world. In fact, according to this tradition of thinking, God purposefully designed an imperfect or unfinished creation with the aim of having it completed and perfected over time. ${ }^{79}$

And not unlike how Islamists emphasize the select nature of those who accept the divine charge to save the world, Jewish thinkers focus on the chosen status of Israel as the people who are divinely elected to repair the world. ${ }^{80}$ Muslims claim that God has elected them to form the umma to save the world, and Jews claim that God has chosen them to form Israel to fix the world. Just as many Jews critique this "Israel first" view and call for a more integrationalist approach, many Muslims also question Islamist 
emphasis on establishing the umma as a discourse of conversion and world domination. ${ }^{81}$

And this overlapping teleological vision can often entail a shared apocalyptic conclusion. Both Jews and Muslims imagine a future where history ends only with the divine intervention of the awaited messianic-led violence and state. ${ }^{82}$ This formula for salvation can involve both repair and destruction, sometimes simultaneously. The Islamic State puts it most simply: all Muslims should (a) perform hijra to join the umma established by the Islamic State in order to (b) engage in jiha $\bar{d}$, with the aim of (c) being martyred (shihāda) to (d) usher in the apocalypse. ${ }^{83}$ Whereas some groups seek to prepare the world for its conclusion by saving and fixing it, others prepare the world for its end by seeking to destroy it. ${ }^{84}$

The same can be said of the United Nations' doctrine of the Responsibility to Protect. In his book-length defense of the doctrine he helped to draft, Gareth Evans claims that the collective nations of the UN not only have the right but the responsibility to save populations from mass atrocities like the Holocaust, the "Purification" purges of Pol Pot, and the killings by the regime of Idi Amin.$^{85}$ Intervention by neighboring states and multinational forces into the internal affairs of certain states, such as Rawanda, Somalia, Bosnia, and Kosovo, are not only required but are mandated by the universal acceptance of human rights principles. More powerful nations, those with the capacity to act, have the greatest responsibility to protect populations when the governments who have sovereignty are not fulfilling their responsibilities.

Yet the record of UN and western interventions for the purpose of protecting at risk populations is uneven, and has not been without criticism. Since the 2005 adoption of the principles contained in the 2001 report of the International Commission on Intervention and State Sovereignty, the UN has intervened with the express purpose of protecting populations from mass atrocities only in Africa and in the Middle East (Kenya in 2008, Ivory Coast in 2011, Libya 2011, Central African Republic in 2013). Resolutions have been passed calling for UN intervention in Darfur (2006), Yemen (2011), Mali (2013), and Sudan $(2011,2013)$. Calls for intervention in both Yemen and Syria have been made, although in both cases military forces from regional and western nations initiated military operations without a UN mandate under the Responsibility to Protect doctrine.

It is not difficult to see why some have accused the UN of using the Responsibility to Protect doctrine as an excuse to target selectively certain 
regimes and populations. NATO intervention in Libya, to implement UN Security Council resolution 1973, targeted the Libyan regime of $\mathrm{Mu}^{\mathrm{c}} \mathrm{am}-$ mar Qadhdhāfi to protect the population opposing the government. In all, close to 6000 Libyan targets were destroyed by the NATO-led coalition, Qadhdhāfĩ was killed, and the old Libyan regime was overthrown. UN-authorized intervention based on the Responsibility to Protect doctrine and UN resolutions referring to the doctrine have, almost exclusively, targeted African states and Muslims in particular: Sudan, Ivory Coast, Libya, Yemen, Central African Republic, Mali. The actors driving and representing the UN are the West and the regimes they support in Africa and the Middle East. In short, Muslims claim they need to protect themselves from the West which claims to be protecting the Muslims from themselves.

In his "What We're Defending," a 70-page English response to an open letter published in the Washington Post in February of 2002 and signed by 60 American academics including Samuel Huntington and Francis Fukiyama, Safar [b. 'Abd al-Raḥmān] al-Ḥawālī accuses the West of hypocrisy.

"There is nothing worse than violating moral values such as freedom and peace, except that the elite group which has chosen itself as defenders of those values are willing instruments of despotism and violence; and nobody is worse than politicians who hurl themselves and their people into the flames of hostilities and wars, except for educators and academics who justify what they do. If this is the case in the land of freedom and democracy, then it is a case of inversion in the world of values, worse than the disaster of destroying a building or the killing of a few thousand people in the material world."

Notice that al-Hawāli utilizes both the language of earlier Islamists and the earlier critiques of Islamist discourse: the elect who claim to defend values but instead support despotism and commit acts of violence, scholars who justify instead of opposing acts of war and tyranny. Not only do the values supposedly "discovered" by America have their roots in Islam (Qadhdhāfî, Khomeini, Quṭb, al-Bannā), but American leadership has deceived the American people and its allies that it actions in the world are designed to protect these values.

Hawālìs treatise does defend the values of freedom and peace but accuses America of the arrogant assumption that it has the monopoly on these values. American actions purportedly aimed at defending these values, such as the "Global War on Terrorism," are, in actuality, a violation of and an attack on these very values. Hawālì claims that American foreign 
policy, especially as it is directed at Muslims and the Middle East, is about imposing a political order that attempts to realize an eschatological utopia patterned after America.

Nearly two hundred years ago Hegel claimed that the end of the dialectic of history had been achieved under the shadow of the mighty Prussian emperor. Marx stole this idea and announced that the end would only come with the establishment of the Proletarian state. When Lenin established this state he made that belief the cornerstone of revolutionary thought which overran half of this planet, and at the end of the century, Professor Fukuyama (whose fingerprints are clearly seen on this open letter) seized upon the fall of the empire of the Proletariat and made the last state to be not Prussia or Russia, but America. At this point, amazingly, he agrees with the "born-again" types one of whom was Reagan (creator of the slogan "Evil Empire" which today has become the "Axis of Evil"), who believe in the coming Millennial Kingdom which they believe will begin around the year 20. It is as if this were a surprising proof for Hegel's critics among the German and other philosophers who claim that he took the idea of the "end of history" from Christianity!

Again using the language of earlier Islamists, al-Hawālī accuses America and the West in general of waging a "destiny-bestowed" or "God-commanded" war to save the world and usher in the end of history.

In his defense against the West's response to 9/11, al-Hawālì recognizes the irony of each side killing the other for the sake of saving the world. Although the "Open Letter" to which al-Hawālī is responding denounces any killing or maiming "in the name of God" its authors also make a lengthy argument that the war against "Islamic extremism" is not only permissible but is required.

Yet reason and careful moral reflection also teach us that there are times when the first and most important reply to evil is to stop it. There are times when waging war is not only morally permitted, but morally necessary, as a response to calamitous acts of violence, hatred, and injustice. This is one of those times. ${ }^{86}$

A comparable point about the irony of this statement is made by William Cavanaugh, director of the Center for World Catholicism and Intercultural Theology, in his critique of what he calls the "myth of religious violence." ${ }^{87}$ The "myth" is that our killing of them is justified to stop their killing of us because their violence is irrationally motivated by religion. Their killing is 
informed by a mistaken interpretation and application of religion, one that does not conform to the ideas of the modern, secular, liberal, democratic nation-state.

And the "Responsibility to Protect" doctrine says we must not only protect ourselves but also protect them from themselves. Like the Muslim pairing of "jihäd wa tabligh", integral to the "protection" afforded by the West is the establishment of "universal" human rights as defined by the West and enshrined in the modern, secular, liberal state. Indeed, how do we differentiate between killing in the name of protecting human rights and killing in the name of saving the world? Between violence designed to preserve freedom and peace, and violence aimed at creating a world free from repression and fear?

\section{Endnotes}

1. Taken from the 2005 World Summit Outcome Document, paragraphs 138139.

2. See Gareth Evans, Mohamed Sahnoun and others, "The Responsibility to Protect," Report of the International Commission on Intervention and State Sovereignty (Ottawa: International Development Research Centre, 2001).

3. On this conference in the context of regional and international politics, see Jean-Pierre Filiu, “The Return of Political Mahdism," Hudson Institute Papers 8 (2009), esp. 30. For the Bright Future Institute in Qom that sponsors the annual conferences, see http://mahdaviat-conference.com/en/default for the English version of the website.

4. See Ibrāhīm al-Musāwī al-Zanjānī, 'Aqā'id al-imāmìyah al-ithnā 'ashariyya (Beirut: Mu'assisa al-A'lamī li-l-Maṭbū'āt, 1973) quoting Muhammad b. Ya ${ }^{c} q u \bar{b}$ al-Kulaynī, al-Kāfī, s.v. Rawdiat. See the English translation in Moojan Momen, An Introduction to Shi ${ }^{i}$ Islam (Oxford: George Ronald, 1985), 166-167.

5. See Ibn Mājah, Sunan, 36; Abū Dāwūd, Sunan, 38. For the Shi'ī traditions, see Shaykh Muhammad b. Nu'mān al-Mufīd, Kitāb al-irshād (Najaf: al-Haydarī Press, 1963), 341; English translation see IKA Howard, Kitāb al-Irshād (London: Balagha Books, 1981), 548.

6. See Mary Anne Weaver, "The Short, Violent Life of Abu Musab al-Zarqawi," The Atlantic (July/August 2006). Also see some of the insights in William McCants, The ISIS Apocalypse: The History, Strategy, and Doomsday Vision of the Islamic State (New York: St. Martin's Press, 2015). 
7. See Abū Dāwūd, Sunan 15:890, 2438, 38:1, 4286; Muslim, Ṣaḥịh, 15:90, 1388, 54:1, 2880. For studies of these traditions, see David Cook, Studies in Muslim Apocalyptic (Princeton: Darwin Press, 2002) and his Contemporary Muslim Apocalyptic Literature (Syracuse: Syracuse University Press, 2008).

8. See Shaykh Muhammad b. Nu'mān al-Mufīd, Kitāb al-irshād, 338, 337; Howard, Kitāb al-Irshād, 544, 542, 548.

9. See the traditions referenced in Muhammad Bāqir al-Majlisī, Biḥ̂ar al-anwār (Tehran: Maṭba'a al-Islāmiyya, 1956-1972), esp. 13:132.

10. See David Johnston, Earth, Empire and Sacred Text: Muslims and Christians as Trustees of Creation (London: Equinox, 2013).

11. For a history of the concept, see Gilbert Rosenthal, "Tikkun ha-Olam: The Metamorphosis of a Concept," The Journal of Religion 85 (2005): 214-240.

12. See the traditions referenced in Shaykh Muhammad b. Nu'mān al-Mufīd, Kitāb al-irshād, 543-544; Howard, Kitāb al-Irshād, 512-513.

13. See Ibn Kathīr, Tafsīr al-Qur'ān al- '́azìm, on Q 3:110-112.

14. See Ibn Mājah, Sunan, 37:4429, cited in Ibn Kathīr, Tafsīr al-Qur'ān al- 'azìm, on Q 3:110-112. Compare Ibn Mājah, Sunan, 37:2624, 4427.

15. See Ahmad b. Hanbal, Musnad, 763.

16. See, for example, al-Tirmidhī, Jāmic al-șahīh, 37:2634.

17. Al-Tirmidhī, Jāmic al-ṣaḥịh, 37:2624; Ibn Mājah, Sunan, 37:4427; al-Bukhārī, Șahīh, 81:21 (479); Muslim, Șaḥiḥ, 1:94 (218).

18. See Ahmad b. Hanbal, Musnad, 120, 22.

19. See Sayyid Quṭ, F̄̄ zilāl al-Qur'ān, 1:441-442 on Q 3:110.

20. Sayyid Quṭb, Ma âlim fì al-țarīq (Cairo: Dār al-Shurūq, 1964), translation taken from Princeton Readings in Islamist Thought: Texts and Contexts from al-Banna to Bin Laden, ed. Roxanne Euben and Muhammad Qasim Zaman (Princeton: Princeton University Press, 2009).

21. See the analysis in Andrew March, "Taking People as They Are: Islam as a 'Realistic Utopia' in the Political Theory of Sayyid Qutb," American Political Science Review 104 (2010): 189-207. On the “jahiliyya”, see William E. Shepard, "Sayyid Qutb's Doctrine of Jahiliyya," International Journal of Middle East Studies 35 (2003): 521-45.

22. See al-Ṭabarī, Jāmi` al-bayān fì ta'wīl al-Qur'ān, on Q 3:110.

23. See Ahmad b. Husayn al-Bayhaqī, Dalā'il al-nubuwwa.

24. See the reference in Jalāl al-Dīn 'Abd al-Rahmān al-Suyūṭi, al-Durr al-manthūr fì tafsīr al-ma'thūr (Beirut: Dār al-Kutub al-'Ilmiyya, 2000), on Q 5:54.

25. For analysis of Ridā's approach to the Qur’an, see Tazul Islam and Israr Ahmad Khan, "Identifying Maqāṣid al-Qur’ān: A Crititical Analysis of Rashīd Riḍās Views," Journal of Islam in Asia 1 (2011): 463-496.

26. On the Ayatollah Khomeini's understanding of Q 3:104 and 110, see Hamid Mavani, Religious Authority and Political Thought in Twelver Shi'ism: From Ali to Post-Khomeini (London: Routledge, 2013), esp. 157; Mavani, 
"Khomeini's Concept of Governance of the Jurisconsult (Wilayat al-Faqih) Revisited: The Aftermath of Iran's 2009 Presidential Election," Middle East Journal 67 (2013): 207-228.

27. On this, see Alexander Nachman, "To Loosen and Bind: Khomeini, Rafsanjani, and Supplemental Governance in the Islamic Republic," British Journal of Middle Eastern Studies (2018); S. Akhavi, "Contending Discourses in Shi'i Law on the Doctrine of Wilāyat al-Faqih," Iranian Studies 29 (1996); Hamid Algar, "Development of the Concept of velayat-i faqih since the Islamic Revolution in Iran" (1998); Hamid Mavani, "Religious Authority and Political Thought in Twelver Shiism: From Ali to Post-Khomeini," Journal of the American Academy of Religion 82 (2013).

28. See al-Suyūțī, al-Durr al-manthūr fì tafsìr al-ma'thür, on Q 3:110.

29. On the overlap between Quṭb and Iran, see Yusuf Ünal, "Sayyid Quṭb in Iran: Translating the Islamist Ideologue in the Islamic Republic," Journal of Islamic and Muslim Studies 1 (2016): 35-60.

30. See Muhammad Maqdsi, "Charter of the Islamic Resistance Movement (Hamas) of Palestine," Journal of Palestine Studies 22 (1993): 122-134, esp. 122. An English translation can be found as part of the Avalon Project, Documents in Law, History and Diplomacy, Lillian Goldman Law Library, Yale Law School, http://avalon.law.yale.edu/20th_century/hamas.asp.

31. Translation taken from Avalon Project, Documents in Law, History and Diplomacy and Maqdisi, "Charter of the Islamic Resistance Movement (Hamas) of Palestine," 123, 124, 125.

32. On Mu'ammar al-Qadhdhāfî̀s use of religious language, see Mahmoud Ayoub, Islam and the Third Universal Theory: The Religious Thought of Mu'ammar al-Qadhdhafi (New York: Routledge, 2017). See Khalil Husayn, al-Qaddāfì wa al-thawra al-islāmiyya ārä’u-hu fì al-dìn wa 'ürūb wa al-mārksiyya (Benghazi: Maktabat al-Andalus, 1973).

33. Mu'ammar al-Qadhdhāfī, al-Nazariyya al-thālitha (Tripoli: al-Ittihād al-Ishritākī al-'Arabī, n.d.).

34. Qadhdhāfî, al-Nazariyya al-thālitha.

35. See al-Tabarī, Jāmi' al-bayān fì ta'wìl al-Qur'ān, on Q 3:110.

36. Qadhdhäfī, al-Nazariyya al-thālitha.

37. For an interesting critque of "crisis" in Qutb's thought, see Yusuf Masud, "Sociological Polytheism: Reading Crisis in Sayyid Qutb," Milestones: Commentary on the Islamic World (December, 2017): 1-10; based on Alasdair MacIntyre, "Epistemological Crises, Dramatic Narrative, and the Philosophy of Science," in The Tasks of Philosophy: Selected Essays, Volume 1 (Cambridge: Cambridge University Press, 2006).

38. On the concept of crisis in Islamic thought, see 'Alī b. 'Abd Allāh ibn 'Alī al-Qarn̄̄, al-Fitra: haqīqatuhā wa-madhāhib al-nās fìhā (Riyadh: Dār al-Muslim li-l-Nashr wa al-Tawzǐi, 2003). Also see George Hourani, "Ghazali 
on the Ethics of Action," Journal of the American Oriental Society 96 (1976): 69-88.

39. See statistics compiled by the World Bank based on data supplied by the United Nations High Comissioner for Refugees, https://data.worldbank.org/ indicator/SM.POP.REFG.OR (accessed December 2018). For Palestinian refugee numbers see the UNRWA website, https://www.unrwa.org (accessed December 2018).

40. For up-to-date statistics, see the UNHCR website of Yemen, https://www. unhcr.org/en-us/yemen-emergency.html (accessed December 2018).

41. See the statistics at the UNHCR website, https://www.unhcr.org/en-us/ (accessed December 2018).

42. See al-Suyūṭī, al-Durr al-manthūr fì tafsìr al-ma 'thūr, on Q 3:110.

43. On the translation of muhäjir as "refugee", see Eva Anne Frantz, "Violence and its Impact on Loyalty and Identity Formation in Late Ottoman Kosovo: Muslims and Christians in a Period of Reform and Transformation," Journal of Muslim Minority Affairs 29 (2009): 455-468; Emin Pllana, "Les raisons de la manière de l'exode des refugies albanais du territoire du sandjak de Nish a Kosove (1878-1878)," Studia Albanica 1 (1985): 189-190; Miloš Jagodić, "The Emigration of Muslims from the New Serbian Regions 1877/1878," Balkanologie: Revue d'Études Pluridisciplinaires 2 (1998): 1-21; Nandita Bhavnani, "Unwanted Refugees: Sindhi Hindus in India and Muhajirs in Sindh," South Asia: Journal of South Asian Studies 39 (2016): 790-804; Papiya Ghosh, "The Changing Discourse of the Muhajirs," India International Centre Quarterly 28 (2001): 57-68.

44. See 'Alī b. Abī Bakr al-Haytamī, Majma' al-zawā’id wa-manba' al-fawā’id (Beirut, 1982), 5:223; al-Muttaqī al-Hindī, Kanz al-'ummāl fì sunan al-aqwāl wa al-af'āl (Hyderabad, 1945-75), 5:469, \#2597 cited in Patricia Crone, “The First-Century Concept of Hijra," Arabica 41 (1994): 352-87, esp. 356.

45. See Ibn al-Mubārak, Kitāb al-jihād, ed. N. Hammād (Beirut, 1971), \#19 cited in Crone, "The First-Century Concept of Hijra," 360.

46. See 'Abd al-Razzāq b. Hammām al-Șan'ānī, al-Mușannaf, ed. H.-R. al-A`ẓamī (Beirut, 1970-1972), 5:9428; Ibn Abī Shayba, Kitāb al-muṣannaffī al-aḥ̄àìth wa al-äthār, ed. M.A. al-Nadwī (Bombay, 1979-1983), 12:12678, 1400; Abū 'Ubayd al-Qāsim b. Sallām, Kitāb al-amwāl, ed. M.Kh. Haras (Cairo 1968), 303, \#523; al-Wāqidī, Kitāb al-maghāzī, ed. M. Jones (London, 1966), 2:757 all cited in Crone, "The First-Century Concept of Hijra," 356-357. Also see Rubin, "Higra wa al-Muhāgirūn," n83.

47. See Ibn al-Mubārak, Kitāb al-jihād, \#164 cited in Crone, "The First-Century Concept of Hijra," 358.

48. See al-Dīnawari, al-Aḥbā al-țiwāl, ed. V. Guirgass (Leiden, 1888), 131 cited in Crone, "The First-Century Concept of Hijra," 357. 
49. See Wilfred Madelung, "Has the Hijra Come to an End?" Revue des études islamiques 54 (1986): 232ff; Alan Verskin, “The Concept of Hijra (Migration) in Medieval Iberia and the Maghreb," in his Islamic Law and the Crisis of the Reconquista: The Debate on the Status of Muslim Communities in Christendom (Leiden: Brill, 2015), esp. 31-32; K. Athamina, "Árab and Muhājirūn in the Environment of the Amșār," Studia Islamica 66 (1987), 9.

50. Șālih b. Fawzān al-Fawzān, "Hijrah of Hearts: The Greatest Kind of Hijrah," https://islamcalling.wordpress.com/2010/03/13/hijrah-of-hearts-the-greatest-kind-of-hijrah/ (accessed March 2019).

51. See al-Fawzān, "Hijrah of Hearts"; Abū Dāwūd, Sunan, 15:849.

52. See, for example, Shaykh Salih al-Fawzaan, “The Types of Hijrah," sahab.net (posted February 28, 2006), accessed 3 February 2019. Also see, Hamizah Binti Hafit and Hafizah Binti Mohd Kamaruzaman, "Meaning and Relevance of Hijrah," Universiti Islam Antarabangsa Malaysi (October 2012), https:// www.academia.edu/9844310/_meaning_and_relevance_of_hijrah_, accessed December 2018.

53. al-Nasā'ì, Sunan, 39:12 (4165).

54. Abū Dāwūd, Sunan, 15:849 (2479).

55. al-Bukhārī, Șaḥīh, 2:4 (10) and see 81:26 (7484).

56. Ibn Mājah, Sunan, 36:2 (3934).

57. Ibn Rushd, al-Mawsū'a al-fiqhiyya, 4:264.

58. See Muhammad b. Aḥmad al-Qurțubī, al-Jāmi 'al-aḥkām al-Qur’ān (Beirut: Dār Ihyā's al-Turāth al-'Arabī, 1985), on Q 4:100.

59. See al-Qurțubī, al-Jāmi` al-aḥkām al-Qur'ān, on Q 4:100.

60. See al-Suyūtị, al-Durr al-manthūr fì tafsīr al-ma'thūr, on Q 8:72

61. See Ibn Kathīr, Tafsìr al-Qur'ān al-'azìm, on Q 8:72.

62. See Zeki Saritoprak, “The Qur'anic Perspective on Immigrants: Prophet Muhammad's Migration and its Implications in our Modern Society," Journal of Scriptural Reasoning 10 (2011), https://jsr.shanti.virginia.edu/back-issues/ vol-10-no-1-august-2011-people-and-places/ (accessed March 2019); Muhammad Saiful Alam Shah Bin Sudiman, "Countering ISIS’s Call for Hijra (Emigration) A Review through the Lens of Maqāṣid ash-Sharī‘ah," Journal for Deradicalization 12 (2017): 60-84.

63. See Abdulrahman Latif, "Be Brothers-Case Studies of Muslim Receptions of Refugees in History” (Yaqeen: Institute for Islamic Research, 2018).

64. See Muslim, Șahīh, 5:3 (521).

65. See Amir Husain, "Toward a Muslim Theology of Migration," in Theology of Migration in the Abrahamic Religions, ed. E. Padilla and P. Phan (New York: Palgrave Macmillan 2014), 173-186; Saritoprak, "Migration and Feelings of Belonging to a Land, and the Universality of Islam," in Islam and Citizenship Education, ed. E. Aslan and M. Hermansen (Wiener Beiträge zur Islamforschung, 2015), 45-54. 
66. See, for example, Hussam Timani, "The Islamic Doctrine of Hijra (Migration)," in Strangers in this World: Multireligious Reflections on Immigration, ed. Hussam Timani et al. (Minneapolis: Fortress Press, 2015), 111-128.

67. See M. Ebstein, "The Connection between Hijra and Jihād in Classical Islam," Jamā'a 15 (2005-2006): 53-85; Verskin, Islamic Law and the Crisis of the Reconquista.

68. See Brannon Wheeler, "From Dar al-Hijra to Dar al-Islam: The Islamic Utopia," in The Concept of Territory in Islamic Law and Thought, ed. Yanagihashi Hiroyuki (New York and London: Kegan Paul International, 2000), 1-36.

69. See 'Alī b. Ibrāhīm al-Halabī, al-Sìra al-Halabiyya, 1:146 cited in Arafat Madi Shoukri, Refugee Status in Islam: Concepts of Protection in Islamic Tradition and International Law (London: I.B. Tauris, 2011), 19.

70. See Ibn Hishām, al-Sìra al-nabawiyya, 1:27; cited in Shoukri, Refugee Status in Islam, 20.

71. See the discussion of the incident in Shoukri, Refugee Status in Islam, 23-27; Michael Lecker, "al-Ṭāiif” and "Thakif", in The Encyclopaedia of Islam, 2nd ed.; Henri Lammens, "La Cité de Ṭāif à la veille de l'hégire," MFOB 8 (1922): 113-327.

72. See Ibn Kathīr, al-Bidāya wa-l-nihāya, 3:137, Ibn Sa'd, Tabaqāt al-kubrā, 1:212, Hassan b. Thābit, 88 and Shoukri, Refugee Status in Islam, 31-33, 2627.

73. See Shoukri, Refugee Status in Islam, 31-33; Watt, Muhammad at Mecca (Oxford, 1953), 35-39.

74. For a general overview, see Wim Raven, "Some Early Islamic Texts on the Negus of Abyssinia," Journal of Semitic Studies 23 (1988): 197-218; Trimmingham, Islam in Ethiopia, 74-78.

75. Cited in Raven, "Some Early Islamic Texts on the Negus of Abyssinia," 199 from Ibn Abī Hātim, 3:441-442. Also see Ibn Ishāq, al-Sīra al-nabawiyya, 217-220. See Watt, Muhammad at Mecca, 68-69; Shoukri, Refugee Status in Islam, 27-33.

76. See Abū Dāwūd, Sunan, 21:1191 and see Raven, "Some Early Islamic Texts on the Negus of Abyssinia," 202.

77. See Abū Dāwūd, Sunan, 15:876 and Muslim, Șaḥịh, 11:22; Bukhari, Șaḥīḥ, 63:48.

78. For a historical overview, see Rosenthal, "Tikkun ha-Olam."

79. On the concept of God allowing evil to persist in the world, see Jon Levenson, Creation and the Persistence of Evil: The Jewish Drama of Divine Omnipotence (Princeton: Princeton University Press, 1994).

80. See the discussion in Gerald Blitstein, “Tikkun Olam," Tradition 29 (1995): $5-43$.

81. See the comments in Rosenthal, "Tikkun ha-Olam." 
82. For an extensive overview, see Kaufmann Kohker, "Eschatology," in The Jewish Encyclopedia (New York: Funk and Wagnalls, 1906), s.v.

83. See the discussions in Justin O'Shea, "ISIS: The Role of Ideology and Eschatology in the Islamic State," Pardee Periodical Journal of Global Affairs 1 (2016): 51-65; Cook, Contemporary Muslim Apocalyptic Literature and his "Fighting to Create the Just State: Apocalypticism in Radical Muslim Discourse," in Just Wars, Holy Wars, and Jihad, ed. Sohail Hashmi (Oxford: Oxford University Press, 2012), 364-382; McCants, The ISIS Apocalypse; Graeme Wood, "What ISIS Really Wants," The Atlantic (March 2015).

84. See the analysis in Robert Lifton, Destroying the World to Save it: Aum Shinrikyo, Apocalyptic Violence, and the New Global Terrorism (New York: Metropolitan Books, 1996); John Gray, Black Mass: Apocalyptic Religion and the Death of Utopia (New York: Penguin, 2007).

85. See Gareth Evans, The Responsibility to Protect: Ending Mass Atrocity Crimes Once and for All (Washington, DC: Brookings Institution Press, 2008), esp. 11-30.

86. "What We're Fighting For: A Letter From America," The Washington Post (February 12, 2002).

87. See William Cavanaugh, The Myth of Religious Violence: Secular Ideology and the Roots of Modern Conflict (Oxford: Oxford University Press, 2009). 